\title{
Analisis Proses Manufaktur Alat Pengepres Geram Mesin Perkakas
}

\author{
Muas $\mathbf{M}^{1}$, Arthur Halik R ${ }^{2}$, Dian Ekawati, Ahmad Hasbullah ${ }^{3}$, Satria Anggara Samudra ${ }^{4}$ \\ 1,2,3,4, Jurusan Teknik Mesin, Politeknik Negeri Ujung Pandang, Makassar 90245, Indonesia \\ *muas@poliupg.ac.id
}

\begin{abstract}
Scattred industrial trash on mechanical company's workshop will be dangerous for operator and employee. The aims of this research are to design, analyze and compare the function of automatic press tool of machining trash to a manual process. Method of this research are designing, manufacturing and testing. A tool was designed using inventor software, assembled and manufactured, then tested. As results, trash becomes neater, smaller, thus easier moved to the recycle process. It can operate with 2 ton maximum pressure and dimention 28,6 cm x 28,6 cm with $25 \mathrm{~cm}$ depth. Press tool produces an average pressing time with an automatic system $21.89 \mathrm{sec}$ and reduction in space volume $7.670,7 \mathrm{~mm}^{3}$, whereas manual process, average pressing time $34,38 \mathrm{sec}$, space volume reduction $5.887,3 \mathrm{~mm}^{3}$.
\end{abstract}

Keywords: manufacture, press tool, machining trash, pressing time, space volume reduction.

\begin{abstract}
Abstrak: Sampah industri yang berserakan di bengkel perusahaan mekanis akan berbahaya bagi operator dan karyawan. Tujuan dari penelitian ini adalah untuk merancang, menganalisis dan membandingkan fungsi alat press geram otomatis dengan proses manual. Metode penelitian ini adalah merancang, membuat dan menguji alat. Alat dirancang menggunakan software inventor, kemudian dirakit dan diproduksi,lalu diuji. Hailnya, sampah menjadi lebih rapi, lebih kecil, sehingga lebih mudah dipindahkan ke proses daur ulang. Alat ini dapat beroperasi dengan tekanan maksimum 2 ton dengan dimensi $28,6 \mathrm{~cm}$ x $28,6 \mathrm{~cm}$ dengan kedalaman $25 \mathrm{~cm}$. Press tool menghasilkan waktu pengepresan rata-rata dengan sistem otomatis 21,89 detik dan pengurangan volume ruang $7,670,7 \mathrm{~mm}^{3}$, sedangkan proses manual, waktu pengepresan rata-rata 34,38 detik, pengurangan volume ruang $5,887,3 \mathrm{~mm}^{3}$
\end{abstract}

Kata kunci : Manufaktur, alat press, sampah geram, waktu press, pengurangan ruang volume

\section{PENDAHULUAN}

Setiap proses permesinan akan menghasilkan sampah produksi yang tentunya tidak dapat digunakan kembali dalam proses produksi kecuali sampah tersebut di daur ulang lagi. Sampah tersebut dapat berupa geram atau serbuk yang apabila bertumpuk dapat membahayakan dan menyebabkan kecelakaan kerja yang bisa menghambat proses produksi. Sampah produksi juga bisa menyebabkan gangguan kesehatan pada pekerja di bengkel atau area proses permesinan.[1,2]

Sampah dapat didaur ulang untuk menghasilkan bahan baru yang kemudian dapat digunakan kembali pada peroses produksi yang lain. Namun, bentuk yang tidak beraturan dari geram tersebut akan menyulitkan proses pemindahan material dari tempat penumpkaan geram ke tempat peleburan atau daur ulang. $[3,4]$

Proses peleburan logam akan lebih mudah apabila logam dibentuk dan dipadatkan (tidak berserakan). Geram yang akan dilebur harus melalui proses pemadatan dari geram yang bentuknya tidak beraturan [5]. Berkaitan hal di atas, penelitian ini dilakukan dengan membuat dan menganalisis suatu alat bantu produksi berupa alat pengepres geram mesin perkakas. Alat tersebut berfungsi untuk mengepres sampah geram hasil permesinan. Sampah geram bisa langsung dimasukan ke dalam alat yang dibuat kemudian dipress. Manfaat yang diperoleh yaitu bisa menghemat tempat, bahaya geram yang berserakan bisa dikurangi dan memudahkan dalam hal pengangkutan ke tempat pengolahan daur ulang atau peleburan sampah geram. 


\title{
II. METODE PENELITIAN
}

Metode penelitian ini adalah dengan melakukan beberapa tahap yaitu perancangan, pembuatan dan pengujian. Alat ini dirancang untuk mengepres sampah geram hasil permesinan. Adapun langkah kerja dan tahapan-tahapan penelitian sebagai berikut

\section{A. Perancangan}

Bahan-bahan dan peralatan yang digunakan antara lain : besi profil $U$ dan L, plat baja $3 \mathrm{~mm}$, elektroda las, pegas tarik, dongkrak hidrolik, baut dan mur, roda, besi hollow, bearing, motor power window, adaptor, switch on/off, mata gerinda potong dan asah, mata bor, cat, thinner, kabel serabut, mesin bubut, mesin bor, mesin gerinda tangan, mesin las SMAW, siku, jangka sorong, tang, kunci pas, mistar baja, palu baja, ragum, mesin bending, penitik, kuas, dan penggores. Desain rancangan alat pengpress geram dapat dilihat pada Gambar 1.

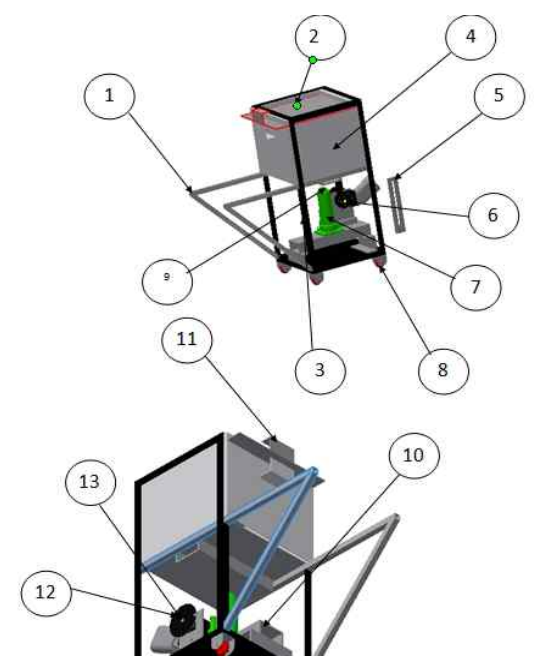

\author{
Keterangan: \\ 1. Punch \\ 2. Dudukan hidrolik dan Motor \\ 3. Handle Penutup \\ 4. Cakram Penggerak Batang \\ 5. Poros Cakram \\ 6. Rel \\ 7. Penutup Bak Geram \\ 8. Rangka \\ 9. Bak Geram \\ 10. Batang Penggarak Piston \\ 11. Motor Penggerak \\ 12. Hodrolik \\ 13. Roda
}

Gambar 1. Desain alat pengepres geram

\section{B. Pembuatan}

Semua komponen yang telah dibuat dirakit berdasarkan gambar kerja dan komponenkomponen standar yang langsung sibeli seperti roda, pegas, bearing, dongkrak hidrolik, switch on/off, adaptor, kabel penghubung dan mesin penggerak otomatis dipasang sesuai tempatnya masing-masing. Mesin pengepres geram yang telah dirakit, diuji coba fungsi komponen-komponennya secara manual kemudian dilanjuttkan pada kondisi mesin dihidupkan. Alat pengepress geram dapat dilihat pada Gambar 1.

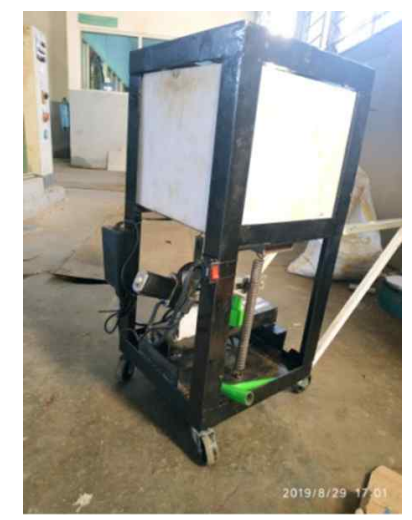

Gambar 1. Alat pengepres sampah geram 
181 Muas M, Arthur Halik R, Dian Ekawati, Ahmad Hasbullah, Satria Anggara Samudra. Analisis Proses Manufaktur Alat Pengepres Geram Mesin Perkakas

\section{Pengujian}

Pengujian alat dilakukan setelah proses pembuatan dan perakitan. Pengujian dilakukan untuk mengetahui apakah alat berfungsi dengan baik dan juga untuk mendapatkan kapasitas dan produksi dari alat. Pengujian dilakukan melalui press manual dan otomatis.

\section{HASIL DAN PEMBAHASAN}

Hasil perancangan dan analisis proses manufaktur alat pengepres geram dihasilkan mesin pengepres geram dengan volume ruang press $204.490 \mathrm{~mm}^{3}$. Alat ini menggunakan hidrolik jack kapasitas 2 ton yang di gerakkan dengan motor penggerak power window dangan daya motor 7,2 $\mathrm{Hp}$ dengan kecepatan motor penggerak $54 \mathrm{rpm}$.

Untuk mengetahui hasil dari alat ini dilakukan pengujian tiap pengepresan dengan berat geram yang berbeda, hasil pengujiannya adalah sebagai berikut:

\section{Hasil press otomatis}

Press otomatis hasilnya dapat dilihat pada Tabel 1.

Tabel 1. Data hasil press otomatis

\begin{tabular}{|c|c|c|c|c|c|c|}
\hline \multirow{2}{*}{ No } & \multirow{2}{*}{$\begin{array}{l}\text { Berat } \\
\text { geram } \\
(\mathrm{kg})\end{array}$} & \multirow{2}{*}{$\begin{array}{l}\text { Waktu } \\
(\mathrm{dtk})\end{array}$} & $\mathrm{V} 1$ & $\mathrm{~V} 2$ & $\begin{array}{l}\text { Pengurangan } \\
\text { volume }\left(\mathrm{Cm}^{3}\right)\end{array}$ & $\begin{array}{l}\text { Kapasitas } \\
\text { pengepresan } \\
\left(\mathrm{Cm}^{3} / \mathrm{dtk}\right)\end{array}$ \\
\hline 1. & $1,25 \mathrm{~kg}$ & 29,29 & $16.604,6$ & $13.087,4$ & $3.517,2$ & 287,64 \\
\hline 2. & $2,13 \mathrm{~kg}$ & 19,12 & $18.976,3$ & $17.749,7$ & $1.227,3$ & 299,5 \\
\hline 3. & $2,35 \mathrm{~kg}$ & 17,25 & $19.876,4$ & $16.950,2$ & $2.926,2$ & 379,4 \\
\hline
\end{tabular}

\section{Hasil press manual}

Data pada Tabel 2 menunjukkan hasil press yang dilakukan secara manual.

Tabel 2. Ddata hasil press manual

\begin{tabular}{|c|c|c|c|c|c|c|}
\hline \multirow{2}{*}{ No } & \multirow{2}{*}{$\begin{array}{l}\text { Berat } \\
\text { geram } \\
(\mathrm{kg})\end{array}$} & \multirow{2}{*}{$\begin{array}{l}\text { Waktu } \\
\text { (dtk) }\end{array}$} & \multicolumn{2}{|c|}{ Volume } & \multirow{2}{*}{$\begin{array}{l}\text { Pengurangan } \\
\text { volume }\left(\mathrm{Cm}^{3}\right)\end{array}$} & \multirow{2}{*}{$\begin{array}{l}\text { Kapasitas } \\
\text { pengepresan } \\
\left(\mathrm{Cm}^{3} / \mathrm{dtk}\right)\end{array}$} \\
\hline & & & V1 & V2 & & \\
\hline 1. & $1,25 \mathrm{~kg}$ & 37,02 & $16.604,6$ & $9.825,1$ & $6.779,5$ & 291,65 \\
\hline 2. & $2,13 \mathrm{~kg}$ & 33,17 & $18.976,3$ & $13.931,2$ & $5.045,1$ & 266,32 \\
\hline 3. & $2,35 \mathrm{~kg}$ & 32,96 & $19.876,4$ & 14.069 & $5.807,4$ & 248,7 \\
\hline
\end{tabular}

\section{Analisis Data}

\section{Press otomatis}

T rata-rata waktu

$$
\begin{aligned}
& =\frac{\Sigma t}{\Sigma f}=\frac{29,29+19,12+17,25}{3} \\
& =21,89 \mathrm{det}
\end{aligned}
$$

Laju pengepresan 1

$$
\begin{aligned}
& =\frac{\text { volume pengurangan ruang press }}{\text { waktu }} \\
& =\frac{28,6 \times 28,6 \times 10,3}{29,29} \\
& =287,64 \mathrm{~cm} 2 / \mathrm{det}
\end{aligned}
$$




$$
\begin{aligned}
\text { Laju pengepresan } 2 & =\frac{\text { volume pengurangan ruang press }}{\text { waktu }} \\
& =\frac{28,6 \times 28,6 \times 7}{19,12} \\
& =299,5 \mathrm{~cm} 2 / \mathrm{det} \\
\text { Laju pengepresan } 3 & =\frac{\text { volume pengurangan ruang press }}{\text { waktu }} \\
& =\frac{28,6 \times 28,6 \times 8}{17,25} \\
& =379,4 \mathrm{~cm} 2 / \mathrm{det} \\
\text { Rata-rata laju pengepres } & =\frac{\Sigma l a j u}{\Sigma f}=\frac{287,6+299,5+379,4}{3} \\
& =322,17 \mathrm{~cm} 2 / \mathrm{det} \\
\text { Rata-rata pengurangan } \mathrm{v} & =\frac{\Sigma V}{\Sigma f}=\frac{3.517,2+1.227,3+2.926,2}{3} \\
& =7.670,7 \mathrm{~mm} 3
\end{aligned}
$$

\section{Press manual}

T rata-rata

$=\frac{\Sigma t}{\Sigma f}=\frac{37,02+33,17+32,96}{3}$

$=34,38 \mathrm{det}$

Laju pengepresan 1

$$
\begin{aligned}
& =\frac{\text { volume pengurangan ruang press }}{\text { waktu }} \\
& =\frac{28,6 \times 28,6 \times 13,2}{37,02}
\end{aligned}
$$

$=291,65 \mathrm{~cm} 2 / \mathrm{det}$

Laju pengepresan 2

$$
=\frac{\text { volume pengurangan ruang press }}{\text { waktu }}
$$$$
=\frac{28,6 \times 28,6 \times 10,8}{33,17}
$$

$=266,32 \mathrm{~cm} 2 / \mathrm{det}$

Laju pengepresan 3

$$
\begin{aligned}
& =\frac{\text { volume pengurangan ruang press }}{\text { waktu }} \\
& =\frac{28,6 \times 28,6 \times 10}{32,96} \\
& =248,7 \mathrm{~cm} 2 / \mathrm{det}
\end{aligned}
$$


183 Muas M, Arthur Halik R, Dian Ekawati, Ahmad Hasbullah, Satria Anggara Samudra. Analisis Proses Manufaktur Alat Pengepres Geram Mesin Perkakas

$$
\begin{aligned}
\text { Rata-rata laju pengepres } & =\frac{\Sigma l a j u}{\Sigma f}=\frac{291,65+266,32+248,7}{3} \\
& =268,89 \mathrm{~cm} 2 / \mathrm{det} \\
\text { Rata-rata pengurangan } \mathrm{v} & =\frac{\Sigma v}{\Sigma f}=\frac{6.779,5+5.045,1+5.807,4}{3} \\
& =5.8877,3 \mathrm{~mm} 3
\end{aligned}
$$

Pengujian hasil pengepresan diketahui bahwa untuk mengepres geram dengan ukuran bak yaitu 28,6 x 28,6 x 25 dilakukan 3 kali percobaan untuk masing-masing hasil press dengan berat yang berbeda-beda. Untuk hasil pengepresan secara otomatis, hasil press dengan berat $1,25 \mathrm{~kg}$ dibutuhkan waktu 29,29 detik dengan laju pengepresan 287,64 detik. Percobaan kedua dengan berat hasil pengepresan 2,13 kg dibutuhkan waktu 19,12 detik dengan laju pengepresan 299,5 detik, percobaan ketiga dengan berat hasil pengepresan 2,35 kg dibutuhkan waktu 17,2 detik dengan laju pengepresan 379,4 detik. Waktu pengepresan rata-rata diperoleh 21,89 detik, dengan pengurangan volume ruang $7.607,7 \mathrm{~mm}^{3}$

Pengepresan secara manual, hasil press dengan berat $1,25 \mathrm{~kg}$ dibutuhkan waktu 37,02 detik dengan laju pengepres 291,65. Percobaan kedua dengan berat hasil pengepresan 2,13 kg dibutuhkan waktu 33,17 detik dengan laju pengepresan 266, dan percobaan ketiga dengan berat hasil pengepresan 2,35 kg dibutuhkan waktu 32,96 detik dengan laju pengepresan 248,7 detik. Waktu pengepresan ratarata diperoleh 34,38 detik, dengan pengurangan volume ruang $5.887,3 \mathrm{~mm}^{3}$

\section{KESIMPULAN}

Telah dihasilkan analisa hasil manufaktur mulai dari identifikai material, proses pembuatan komponen dan perakitannya Press tool menghasilkan waktu pengepresan rata-rata dengan sistem otomatis 21,89 detik dan pengurangan volume ruang $7,670,7 \mathrm{~mm}^{3}$, sedangkan proses manual, waktu pengepresan ratarata 34,38 detik, pengurangan volume ruang $5.887,3 \mathrm{~mm}^{3}$

\section{DAFTAR PUSTAKA}

[1] Adriansyah, J.. Pengaruh Radius Pemutus Geram Pahat Bubut Hss TerhadaPanjang Geram Pada Proses Pembubutan. Jurnal Ilmiah Poli Rekayasa Volume. (ISSN : 1858-3706), 10. Jakarta: 2007

[2] Bambode , A.e.. Hydraulic jack for heavy vehicles. Intenasional jourmal Of Innovative Research In Science \& Technology. US: 2015

[3] Budi, F.. "Cara Kerja Mesin Press Hidraulik". Jurnal Departemen Teknik Mesin Fakultas Teknik Industri. Surabaya: Universitas Kristen Petra. 2014

[4] Ferlind Faniel dkk.. "Laporan Tugas Akhir Mesin Pencacah Es Balok". Jurusan Teknik Mesin. Makassar: Politeknik Negeri Ujung Pandang. 2015

[5] Indah Nur, Mus Baehaqi. Desain Dan Perancangan Alat Pengepres Geram Sampah Mesin Perkakas. Jurnal Jurusan Teknik Mesin Fakultas Teknik. Jakarta: Universitas Mercubuana. 2017. 